\title{
MISJA EDUKACYJNA KRAKOWSKICH I LWOWSKICH FILOLOGÓW KLASYCZNYCH NA ŁAMACH PRASY SPECJALISTYCZNEJ (1918-1939)
}

\author{
Małgorzata Pawlak \\ Uniwersytet Wrocławski \\ Karol Sanojca \\ Uniwersytet Wrocławski
}

\begin{abstract}
THE EDUCATIONAL MISSION OF CLASSICAL PHILOLOGISTS FROM LVIV AND CRACOW AS REFLECTED IN SPECIALIST PRESS IN YEARS 1918-1939
\end{abstract}

The academic circle of classical philologists from the Jagiellonian University in Cracow and the University of Jan Kazimierz in Lviv, was dedicated not only to the research and teaching activity but also to popularizing classical antiquity studies. The university professors and lecturers were closely associated with secondary schools, where they were, at the same time, middle school teachers and authors of school course books. The significance of classical education was reinforced and promoted in their various fields of activity. This mission was mainly fulfilled by means of publications in specialist press, i.e. Kwartalnik Klasyczny [The Classical Quaterly], Przeglad Klasyczny [The Classical Review], Eos, Filomata and Palaestra. The journals comprised articles on popular science and didactics, reviews of publishing houses and information on organizational life (primarily on the Polish Philological Society and various school philological clubs). This was also where classical philologists shared their views on current educational issues in The Second Polish Republic.

Key words: classical studies, antiquity, education, the Jagiellonian University in Cracow, the University of Jan Kazimierz in Lviv, paper writing, Kwartalnik Klasyczny, Przegląd Klasyczny, Eos, Filomata, Palaestra.

Słowa kluczowe: filologia klasyczna, antyk, edukacja, Uniwersytet Jagielloński, Uniwersytet Jana Kazimierza, czasopiśmiennictwo, „Kwartalnik Klasyczny”, „Przegląd Klasyczny”, „Eos”, „Filomata”, „Palaestra”.

Adresy do korespondencji: malgorzata.pawlak@uwr.edu.pl; karol.sanojca@uwr.edu.pl 
Zaangażowanie lwowskich i krakowskich uniwersyteckich filologów klasycznych w edukację szkolną w okresie międzywojennym nie zostało dotychczas kompleksowo omówione ${ }^{1}$. Aktywność ta, będąca kontynuacją ścisłych związków pomiędzy uniwersytetami a szkołami średnimi, powstałych dzięki dziewiętnastowiecznym reformom oświatowym, przejawiała się w wielu dziedzinach, a jedną z najbardziej widocznych była działalność na łamach czasopism, głównie popularnonaukowych, przeznaczonych przede wszystkim dla nauczycieli i młodzieży szkolnej. Realizowana w ten sposób „misja edukacyjna” obejmowała kilka kwestii, chociażby udział w dyskusji na temat fundamentalnych spraw dotyczących kształtu ustroju szkolnego i wykształcenia klasycznego. Do tego dodać można wypowiedzi, w których poruszano bardziej szczegółowe problemy z zakresu metodyki nauczania języków klasycznych. Ważnym elementem oddziaływania na szkołę było propagowanie wiedzy o starożytności i autorach antycznych, co przejawiało się w tekstach o charakterze popularnym, prezentujących jednostkowe zagadnienia, mogących stanowić pożywkę intelektualną i pomoc dydaktyczną dla nauczyciela i ucznia. Podobnemu celowi służyła popularyzacja najnowszych osiągnięć naukowych, nie tylko z zakresu filologii klasycznej, ale także z dziedzin pokrewnych (zwłaszcza archeologii i papirologii), prezentacja postaci wybitnych filologów oraz sprawozdania z życia naukowego działalności Polskiego Towarzystwa Filologicznego i kółek filologicznych (nauczycielskich i uczniowskich). Nieodzowną część edukacji filologicznej stanowił wówczas bezpośredni kontakt z kulturą klasyczną, realizowany przez wyjazdy do krajów śródziemnomorskich. Szczegółowe opisy tych podróży wielokrotnie zamieszczano na łamach periodyków - swoje peregrynacje opisywali zarówno profesorowie gimnazjalni, jak i uniwersyteccy ${ }^{2}$.

Najważniejsze forum dyskusji pedagogicznych stanowiły przede wszystkim „Kwartalnik Klasyczny” (1927-1934) i jego kontynuacja „Przegląd Klasyczny”

1 Władysław Madyda, kreśląc dzieje filologii klasycznej na UJ, skupił się wyłącznie na działalności naukowej i organizacyjnej profesorów (W. Madyda, Z dziejów filologii klasycznej w Uniwersytecie Jagiellońskim [w:] Wydziat Filologiczny Uniwersytetu Jagiellońskiego. Historia katedr, red. W. Tas sycki, A. Zaręba, Kraków 1964, s. 1-94. Drugie rocznicowe wydawnictwo, czyli seria „złotych ksiąg” prezentująca osiągnięcia Wydziału Filologicznego UJ, zawiera wyłącznie biogramy (Złota Księga Wydziału Filologicznego, red. J. Michalik, W. Walecki, Kraków 2000). Tematyki dydaktycznej nie porusza też syntetyczne opracowanie dostępne na stronie internetowej UJ (Historia filologii klasycznej na Uniwersytecie Jagiellońskim, http://www.ifk.filg.uj.edu.pl/historia [dostęp: 15.09.2017]). Także podstawowe opracowania dziejów Uniwersytetu Jana Kazimierza nie uwzględniają tej problematyki (J. Draus, Uniwersytet Jana Kazimierza we Lwowie 1918-1946, Kraków 2007; Uniwersytet Jana Kazimierza we Lwowie. Academia militans, red. A. Redzik, Kraków 2015, s. 587-595). Na temat relacji uczelni ze szkołami zob. J. Dybiec, Uniwersytet Jagielloński a szkolnictwo średnie (1918-1939) [w:] Ojczyzna bliższa i dalsza. Studia historyczne ofiarowane Feliksowi Kirykowi w sześćdziesiąta rocznicę urodzin, red. J. Chrobaczyński, A. Jureczko, M. Śliwa, Kraków 1993, s. 560-569.

2 Omówienie aktywności całego środowiska filologów klasycznych wykraczałoby znacznie poza ramy jednego artykułu, dlatego dokonano zawężenia w zasadzie do pracowników katedr filologii klasycznej (profesorów, docentów i lektorów) dwóch uczelni - UJ i UJK. W szczególności nie sposób nie docenić udziału w życiu naukowym licznego grona gimnazjalnych nauczycieli łaciny i greki, którzy publikowali teksty w specjalistycznych czasopismach. Problem ten zasługuje jednak na osobne opracowanie. 
(1935-1939)3 , które adresowane były głównie do pedagogów szkół średnich - nauczycieli języków klasycznych. Bardziej przystępny charakter miały czasopisma „Filomata” (1929-1939) i wydawana nieregularnie „Palaestra” (1930-1936), oba nastawione na młodzieżowego czytelnika. Ugruntowaną pozycją w środowisku naukowym cieszył się rocznik „Eos” o galicyjskiej proweniencji, ale po 1918 roku już ogólnopolski, regularnie wychodzący przez całe dwudziestolecie międzywojenne ${ }^{4}$. Fakt, że zamieszczano tam przeważnie teksty w języku łacińskim, ograniczał jednak krąg odbiorców. „Eos” miał z założenia naukowy charakter i tematyka edukacyjna nie stanowiła głównej osi zainteresowania redakcji, teksty o charakterze dydaktycznym pojawiały się tam więc incydentalnie. Sytuacja zmieniła się od roku 1935, gdy po likwidacji „Kwartalnika Klasycznego” „Eos” przejął de facto realizowane przez niego funkcje i zmienił formułę - stając się kwartalnikiem i włączając w zakres swoich zainteresowań także kwestie związane $\mathrm{z}$ dokumentowaniem życia naukowego i organizacyjnego oraz dydaktyką szkolną. Przyciągnął też autorów, którzy kontynuowali tam swoje cykle tematyczne. Symbolicznym przejawem tej metamorfozy była zmiana tytułu czasopisma na „Eos. Kwartalnik Klasyczny” i publikacja większości tekstów w języku polskim. W wymienionych wyżej czasopismach publikowali lub zasiadali w komitetach redakcyjnych: Seweryn Hammer, Jerzy Schnayder, Tadeusz Sinko i Gustaw Przychocki z Uniwersytetu Jagiellońskiego oraz Marian (Majer) Auerbach, Adolf Bednarowski, Edmund Bulanda, Władysław Chodaczek, Ryszard Ganszyniec, Jerzy Kowalski, Jan Smereka i Franciszek Smolka z Uniwersytetu Jana Kazimierza ${ }^{5}$.

Periodyczne piśmiennictwo filologiczne najwięcej zawdzięcza osobie Ryszarda Ganszyńca ${ }^{6}$, profesora Uniwersytetu Jana Kazimierza we Lwowie. Jego działalność redaktorska rozpoczęła się już na początku lat 20., gdy został współredaktorem wydawanego przez Polskie Towarzystwo Filologiczne rocznika „Eos” i sprawował tę funkcję do połowy lat 30. Był też redaktorem i wydawcą założonego w 1927 roku i firmowanego przez PTF „Kwartalnika Klasycznego”, wokół którego skupił liczne grono współpracowników, wywodzących się nie tylko z kręgów uniwersyteckich

3 A. Lewartowicz, ,, Przeglad Klasyczny”, „Meander” R. 69, 2014, s. 141-161.

4 Przykładowo na 27 osób publikujących w roczniku 1926 z Krakowa i Lwowa pochodziło łącznie 15, czyli ponad 55\% (a następnym roczniku nawet 60\%). Byli to: Seweryn Hammer, Jerzy Krókowski, Kazimierz Kumaniecki, Jakób Mulbegat-Holler, Jerzy Schnayder i Tadeusz Sinko (Kraków) oraz Marian Auerbach, Edmund Bulanda, Władysław Chodaczek, Ryszard Ganszyniec, Jerzy Kowalski, Stanisław Pilch, Artur Rapaport, Franciszek Smolka, Wincenty Śmiałek (Lwów).

${ }_{5}$ Z obszernej literatury poświęconej wymienionym badaczom zob. np.: I. Kaczor, Znaczace postacie łódzkiej filologii klasycznej: Jan Oko, Jerzy Schnayder, Marian Golias, Stefan Oświecimski, „Collectanea Philologica” 2003, vol. 7, s. 97-101; K. Królczyk, Polscy badacze starożytności na Uniwersytecie Lwowskim (1873-1939) - szkic do portretu [w:] „Haec mihi in animis vestris templa”. Studia classica in Memory of Professor Lesław Morawiecki, oprac. P. Berdowski, B. Blahaczek, Rzeszów 2007, s. 23-46; M. Plezia, Kazimierz Morawski, ,Rocznik Biblioteki PAN w Krakowie” R. 31, 1986, s. 79-97; idem, Gustaw Przychocki, „Meander” R. 39, 1984, s. 57-78.

6 Po 1945 r. używał on nazwiska Gansiniec. I. Bieżuńska-Małowist, Ryszard Gansiniec (18881958), „Meander” R. 13, 1958, s. 301-306; R. Turasiewicz, Ryszard Ganszyniec jako historyk greckiej literatury, „Meander” R. 44, 1989, s. 369-382. 
z całej Polski, lecz także spośród nauczycieli gimnazjalnych i członków własnego seminarium filologicznego 7 . Po roku wydawania „Kwartalnik Klasyczny” zyskał uznanie Ministerstwa Wyznań Religijnych i Oświecenia Publicznego. Zaleciło ono dyrekcjom szkół średnich nabywanie go do uczniowskich i nauczycielskich bibliotek szkolnych $^{8}$. W 1929 roku Ganszyniec założył też we Lwowie „Filomatę” - pierwsze pismo filologiczne przeznaczone dla młodzieży. Miesięcznik ten ukazywał się nieprzerwanie do wybuchu wojny (łącznie 111 numerów) i został wznowiony (także przez niego) w 1957 roku już w Krakowie. Również do uczniów skierowane było pisemko „Palaestra” propagujące obecność łaciny w kulturze polskiej. Planowane jako dwutygodnik ukazywało się jednak nieregularnie i łącznie wydano jedynie kilkanaście numerów. Po konflikcie z PTF w 1935 roku Ganszyniec założył kolejne czasopismo - „Przegląd Klasyczny” - starając się zachować jego popularnonaukowy i dydaktyczny charakter?.

Pojawienie się pod koniec lat 20. nowych czasopism nie było przypadkowe, gdyż wiązało się z ogólnym ożywieniem ruchu filologicznego w odpowiedzi na przemiany dokonujące się w polskim szkolnictwie. Tocząca się od kilku dziesięcioleci debata o miejscu gimnazjum klasycznego postawiła przed tym problemem władze oświatowe odrodzonego państwa polskiego ${ }^{10}$. Nałożyło się to dodatkowo na postulat szkoły jednolitej i dążenie do zwiększenia roli przedmiotów matematyczno-przyrodniczych jako bardziej przystających do wymogów współczesności. Zmiany programowe w szkolnictwie dokonane na początku lat 20., polegające na ograniczeniu zakresu nauczania języków klasycznych (a zwłaszcza greki) oraz kolejne projekty reform stały się katalizatorem działań w obronie wykształcenia klasycznego. W akcję tę zaangażowali się filolodzy uniwersyteccy, próbując racjonalnie uzasadnić wartość tradycyjnego modelu wykształcenia. Ich wysiłki zauważane były nawet na łamach prasy codziennej. W 1930 roku „Dziennik Lwowski” opublikował na ten temat specjalny artykuł, w którym konstatowano, że „Philologia militans - »filologia wojująca«, przeforsowała w Polsce swój krytyczny Rubikon, a śmiałe do niedawna falangi atakujących ją przeciwników cofają się w porządku, ale z sercem na ramieniu. I kto wie, czy nie poniosą klęski, gorszej od Persów i Kartagińczyków. Bo tak się coś zdaje, że skazany na śmierć klasycyzm znajduje się dzisiaj u nas u wrót jeszcze jednego

7 Na przywołanie zasługuje tu sylwetka Heleny Matakiewicz, która po ukończeniu studiów na UJK w 1928 r. została asystentką w seminarium R. Ganszyńca, przez krótki okres była też nauczycielką w Gimnazjum im. Królowej Jadwigi we Lwowie. W latach 1929-1932 z zaangażowaniem uczestniczyła w redagowaniu „Kwartalnika Klasycznego”. Publikowała w nim liczne drobne teksty, zwłaszcza recenzje w dziale „Bibliografia” oraz informacje o życiu naukowym w „Kronice”. Po jej przedwczesnej śmierci w 1932 r. R. Ganszyniec poświęcił jej obszerne, wzruszające wspomnienie ([R. Ganszyniec], Helena Matakiewicz [1906-1932], „Kwartalnik Klasyczny” [dalej: KK] 1932, z. 2, s. 235-240).

8 Polecenie „Kwartalnika Klasycznego” przez Ministerstwo WRiOP, KK 1928, z. 2, s. 217.

9 Nowe czasopismo, „Przegląd Klasyczny” [dalej: PK] 1935, z. 1, s. 63, 65; Oświadczenie Wydziatu Zarzadu Głównego PTF w przedmiocie wystapień p. R.G. w „Przegladzie Klasycznym”, „Eos” R. 39, 1938, z. 1, s. 160.

10 Szerzej zob. W. Popiak, Łacina i greka w polskiej szkole w latach 1919-1939. Programy, meto$d y$, podręczniki, Warszawa 2005, s. 13-45. 
swego renesansu, zapatrzony w świtające blaski jutrzenki" ${ }^{11}$. Autor tych słów, Stanisław Łempicki, podkreślał zwłaszcza zasługi dwóch najbardziej zagorzałych obrońców filologii klasycznej - Tadeusza Sinki, profesora UJ, i Ryszarda Ganszyńca, profesora Uniwersytetu Jana Kazimierza we Lwowie: „Bo Ganszyniec i Sinko - to dwaj atleci i kopijnicy tej gorącej walki, która się u nas toczy o byt lub niebyt filologii klasycznej"12.

Oczywiście w tym „boju” o filologię klasyczną nie byli osamotnieni. Na łamach „Kwartalnika Klasycznego” licznie wypowiadano się w sprawie ustroju szkolnictwa, programów i planów nauczania, a w szczególności zachowania pozycji gimnazjum klasycznego z szerokim zakresem nauczania łaciny $i$ greki ${ }^{13}$. Jednym $z$ argumentów było tu podkreślanie miejsca filologii klasycznej w realizacji ideałów wychowawczych, a szczególnie nowej idei wychowania państwowego. Na przykład Jan Smereka postulował taki dobór tekstów autorów antycznych, aby lepiej propagowały one cnoty obywatelskie. Wnosił więc o ograniczenie lektury pamiętników Cezara, zalecał zmianę akcentów przy omawianiu dzieła Liwiusza (zamiast księgi I i II raczej XXI i XXII 43-51), twierdził, iż szczególny nacisk należy położyć na nieco inne fragmenty pism filozoficznych Cycerona (zwłaszcza De officiis - O powinnościach). W wypadku utworów greckich domagał się też zmian w doborze fragmentów dzieł Platona (Kriton i wybrane ustępy z Rzeczypospolitej) oraz przywrócenia na listę lektur Demostenesa ${ }^{14}$. Za swoiste podsumowanie tej dyskusji mogą posłużyć słowa Ganszyńca, który patetycznie opisał rolę humanizmu w wychowaniu i cele, jakie taka edukacja powinna sobie stawiać. Uważał bowiem, że chodzi o „wżycie się w świat i mentalność starożytnych, byśmy w kongenialnym trudzie mogli urzeczywistnić wszystkie ideały intelektualne i artystyczne humanizmu, etyczne człowieczeństwa, społeczne humanitaryzmu i w ten sposób wskrzesić Helladę w Polsce odrodzonej"15.

Tematy poruszane $\mathrm{w}$ periodykach filologicznych obejmowały szerokie spektrum zagadnień związanych z metodyką nauczania języków klasycznych. Kwestie teoretyczne podejmował Tadeusz Sinko, publikując rozważania o potrzebie równoległego pogłębiania znajomości formalnej języków klasycznych i wiedzy o świecie antycznym oraz charakteryzując ewolucję pojęcia humanizmu i jego rolę w nauczaniu szkolnym ${ }^{16}$. Jan Smereka uważał, że bez znajomości zasad retoryki trudno uczyć o poezji i historiografii antycznej ${ }^{17}$, a Ryszard Ganszyniec podnosił kwestie wymowy oraz pisowni greckiej i łacińskiej, występując przeciw „,anarchii ortograficznej” w za-

11 S.Ł. [S. Łempicki], Philologia militans, „Gazeta Lwowska”, 29 X 1930, nr 250, s. 4.

12 Ibidem.

13 M. Golias, Nauka języków klasycznych w programie naszej szkoty średniej, KK 1927, z. 1, s. 16-26; J. Kowalski, PTF w sprawie Projektu Ustawy o ustroju szkolnictwa, KK 1928, z. 1, s. 45-57.

14 J. Smereka, Filologia klasyczna wobec zagadnienia szkoła i państwo, KK 1930, z. 3, s. 453-466. Smereka postulował też przygotowanie i opublikowanie specjalnego zeszytu, który ukazywałby na podanych przez niego przykładach rolę Cycerona w wychowaniu młodzieży rzymskiej (idem, Cyceron nauczycielem i wychowawca Rzymian, „Eos” R. 39, 1938, z. 4, s. 504-514).

15 R. Ganszyniec, Rola humanizmu w wychowaniu, „Filomata” 1938, nr 105, s. 147-157.

16 T. Sinko, Dyscyplinaryzm i realizm, KK 1928, z. 4, s. 383-388; idem, Dzisiejsze humanizmy, zwłaszcza ten trzeci, „Eos” R. 37, 1936, z. 3, s. 308-327.

17 J. Smereka, O retoryce w szkole średniej, KK 1929, z. 3, s. 289-308. 
pisie imion antycznych ${ }^{18}$. Upominał się też o rozróżnianie w nauce szkolnej religii od mitologii. Uważał, że w programie gimnazjum powinno się znaleźć miejsce na nauczanie dziejów religii starożytnych, nawet kosztem opowieści mitologicznych. Wskazywał przy okazji na analogie pomiędzy religiami starożytnymi a współczesnym chrześcijaństwem ${ }^{19}$. W 1934 roku Schnayder zabrał głos w sprawie kanonu lektur autorów łacińskich, proponując jego urozmaicenie i dostosowanie do nowych okoliczności. Okazją do rewizji tego zestawu była między innymi reforma Janusza Jędrzejewicza, która powołała do życia licea ogólnokształcące (pierwszy rocznik miał zacząć w nich naukę w 1937 r.). Wzorem szkoły niemieckiej i austriackiej Schnayder opowiadał się za stworzeniem (zamiast tradycyjnych czytanek) serii tematycznych broszur zawierających odpowiednio dobrane fragmenty dzieł antycznych ${ }^{20}$. Bednarowski z kolei zauważał potrzebę korelacji pomiędzy gimnazjalną nauką religii i łaciny. Ukazywał możliwości utrwalania znajomości języka łacińskiego na lekcjach religii i w czasie nabożeństw oraz proponował przykłady ćwiczeń z translacji tekstów liturgicznych na język polski² ${ }^{21}$.

Bardziej szczegółowe kwestie dotyczyły roli i sposobu nauczania gramatyki łacińskiej $^{22}$. W związku $\mathrm{z}$ wejściem w życie nowego programu gimnazjalnego i opublikowaniem podręczników Tadeusza Lewickiego Primitiae Latinae oraz Jerzego Kowalskiego i Mariana Goliasa Puer Romanus Sinko zaproponował zmianę kolejności przyswajania przez uczniów deklinacji i koniugacji, co miałoby wpłynąć pozytywnie na wyniki nauczania ${ }^{23}$. Przeglądu metod tłumaczenia tekstów antycznych i sposobów dostosowania ich do praktyki szkolnej (na konkretnych przykładach) dokonał Golias $^{24}$. Jednym z jego postulatów było też upowszechnienie w nauczaniu łaciny i greki metod neofilologicznych, w tym odejście od tradycyjnego „gramatycyzmu”25. Krytykę owego „gramatycyzmu” (zaliczanego przez autora do „parafilologii”) jako metody służącej poznaniu języka zawarł też w swoim artykule Ganszyniec ${ }^{26}$. Auerbach w tekście zatytułowanym Problem zasobu wyrazów w języku łacińskim koncentrował zaś swoją uwagę na sposobach pomocy uczniowi w przyswojeniu jak największej liczby słówek łacińskich. Uważał przy tym, że znajomość słownictwa jest niezbędna do prawidłowego tłumaczenia i rozumienia tekstów antycznych. Nie tylko odniósł się do metod nauczania (działań nauczyciela) i technik pracy uczniowskiej, ale tak-

18 R. Ganszyniec, O reforme wymowy tacińskiej w gimnazjach polskich, KK 1934, z. 3, s. 245247; idem, O pisownię imion greckich i rzymskich, KK 1928, z. 1, s. 44; idem, Pisownia imion greckich i rzymskich, KK 1930, z. 1, s. 53-64.

19 Idem, Mythologia a religia klasyczna w szkole, KK 1933, z. 3, s. 189-210; idem, Mythos a historia, PK R. 4, 1938, z. 10, s. 707-715.

20 J. Schnayder, W sprawie lektury autorów tacińskich w nowej szkole średniej, KK 1934, z. 3, s. $177-186$.

${ }_{21}$ A. Bednarowski, Nauka religii i łaciny w nowym gimnazjum. Próba korelacji, KK 1934, z. 4, s. $249-257$.

22 M. Auerbach, Rola gramatyki tacińskiej w gimnazjum, KK 1928, z. 1, s. 39-43.

23 T. Sinko, Porzadek deklinacji i koniugacji tacińskich w nauce szkolnej, KK 1934, z. 1, s. 33-35.

24 M. Golias, O metodę rozumienia tekstów tacińskich w szkole, KK 1934, z. 1, s. 9-21.

${ }_{25}$ Idem, Neofilologiczne metody w nauczaniu języka tacińskiego, „Eos” R. 38, 1937, z. 4, s. 526-541.

26 R. Ganszyniec, Filologia a parafilologia, PK R. 5, 1939, z. 6-8, s. 449-464. 
że sformułował postulaty pod adresem autorów podręczników, określając warunki, które sprzyjają zapamiętywaniu słownictwa: kontekstowe poznawanie nowych terminów (w sensie semantycznym i gramatycznym), łączenie tekstu z obrazem zgodnie z zasadą poglądowości, indukcyjne dochodzenie do formułowania pojęć, rozbudowanie informacji słownikowych o definicje bądź synonimy oraz grupowanie wyrazów według treści i związków etymologicznych ${ }^{27}$. Praktyczne porady dla uczniów o sposobach pamięciowego przyswajania słownictwa przedstawił też Go$\operatorname{lias}^{28}$. Teoretyczne refleksje profesorów uniwersyteckich nad dydaktyką szkolną nie powstawały w próżni - dobry materiał poglądowy ukazujący realia szkolnej filologii klasycznej przynosiły ankiety przeprowadzane wśród kadry nauczycielskiej ${ }^{29}$.

Wiele emocji budziły zamieszczane w czasopismach recenzje i omówienia podręczników szkolnych. Dyskusje na tematy podręcznikowe toczyły się publicznie, przybierając nieraz ostre formy. Spór o wzajemne relacje między dwoma podręcznikami gramatyki łacińskiej ${ }^{30}$ podzielił środowisko, urastając wręcz do rangi krakowsko-lwowskiego konfliktu. Sprawę relacjonował „Kwartalnik Klasyczny”, publikując: rezolucję Krakowskiego Koła PTF zarzucającą Auerbachowi plagiat z podręcznika Sinki; teksty referatów Schnaydera i Hammera, na których oparto te zarzuty; odpowiedź Auerbacha oraz wystosowane w jego obronie pismo Lwowskiego Koła PTF ${ }^{31}$. Sam Sinko polemizował także w sprawie swojego podręcznika do gramatyki z niepochlebną opinią opublikowaną przez Józefa Rączego (profesora gimnazjum w Rzeszowie). Recenzja ta stanowiła poniekąd kontynuację sporu Sinko-Auerbach. Jej autor, sprowokowany „wyprawą krakowskiego koła PTF na p. Auerbacha”, brał w obronę tego ostatniego, między innymi znajdując w książce Sinki zapożyczenia ze starszych podręczników ${ }^{32}$. Pozytywną ocenę dzieła Auerbacha sformułował też Smolka, dość krytycznie oceniając dotychczas stosowane książki do gramatyki łacińskiej. Skrytykował też podręcznik Sinki, stwierdzając, że „nie zaspokoił potrzeby nowego podręcznika raz dlatego, że nie jest należycie przemyślany, jest trudny, w szczegółach zawiera rzeczy nieścisłe, a po wtóre dlatego, że napisał go wybitny wprawdzie uczony, ale równocześnie człowiek, który z praktyką szkolną niezmiernie mało i bardzo dawno miał do czynienia" ${ }^{33}$. W recenzji tej Smolka zawarł też ogólne refleksje na temat miejsca gramatyki łacińskiej w nauczaniu szkolnym,

27 M. Auerbach, Problem zasobu wyrazów w języku łacińskim, KK 1933, z. 2, s. 93-106.

28 M. Golias, Jak uczyć się na pamięć?, „Filomata” 1930, nr 12, s. 59-63.

29 Idem, Nauka języka tacińskiego w klasie II w świetle ankiety, „Eos” R. 36, 1935, z. 3, s. 337-348; idem, Nauka języka tacińskiego w klasie III w świetle ankiety, „Eos” R. 37, 1936, z. 4, s. 494-512.

30 T. Sinko, Gramatyka tacińska, Warszawa-Poznań 1924 (wyd. 2, 1925, wyd. 3, 1930); M. Auerbach, Gramatyka tacińska, Lwów 1929.

31 Sinko contra Auerbach, KK 1930, z. 3, s. 526-538.

32 J. Rączy, Łacińskie gramatyki szkolne, a szczególnie prof. Sinki w wydaniu 1 i 2, KK 1931, z. 1, s. 60-64; T. Sinko, W sprawie uwag J. Raczego o tacińskich gramatykach szkolnych, KK 1931, z. 3, s. 456-461; J. Rączy, O III deklinacji łacińskiej w Gramatyce prof. Sinki i o jego sztuce nicowania, KK 1931, z. 3, s. 462-474. W obronie podręcznika Puer Romanus polemikę na łamach KK podjął także jego współautor M. Golias (W odpowiedzi, „Eos” R. 36, 1935, z. 2, s. 205-208).

${ }_{33}$ F. Smolka (rec.), M. Auerbach, Gramatyka tacińska. Podręcznik do użytku szkót średnich, Lwów 1929, KK 1930, z. 1, s. 220-222. 
formułując zbiór postulatów. Uważał, że uczeń przez cały okres nauki w gimnazjum powinien posługiwać się jednym podręcznikiem gramatyki obejmującym wymowę (fonologię), morfologię i składnię. Książka powinna uwzględniać najnowszy stan badań. Rezultatem korzystania z podręcznika powinno być zrozumienie istoty zmian językowych (z uwzględnieniem aspektu genetycznego i psychologicznego). Wśród zagadnień gramatycznych należy wyodrębnić część dogmatyczną i objaśniającą. Gramatyki łacińskiej należy nauczać, uwzględniając aspekt historyczny oraz odnosząc się przy tym do języka staropolskiego i współczesnej polszczyzny. W konkluzji recenzji Smolka stwierdził, że podręcznik Auerbacha w dużej mierze realizuje te postulaty.

Oprócz podręczników omawiano też inne pomoce szkolne. Auerbach zalecał na przykład wykorzystywanie przy organizowaniu sprawdzianów pisemnych broszur z tekstami łacińskimi wydawanych przez „Filomatę”. Według autora pozwalały one nauczycielowi na różnicowanie poziomu wymagań, przy uwzględnieniu możliwości percepcyjnych uczniów ${ }^{34}$. Podnoszono też potrzebę tworzenia komentarzy językowych i rzeczowych przeznaczonych do nauki szkolnej, podkreślając ich znaczenie zwłaszcza w pracy domowej ucznia ${ }^{35}$. Golias postulował tworzenie pracowni filologicznych, gromadzących zbiory pomocy naukowych, które miały ułatwiać realizację zasady poglądowości i pozwalać na pobudzenie aktywności uczniów. Powinny się w niej znaleźć: słowniki, preparacje, tłumaczenia, faksymile rękopisów i papirusów, komplet numerów „Filomaty”, obrazy, tablice poglądowe, odlewy gipsowe i epidiaskop $^{36}$. Ganszyniec był natomiast wielkim zwolennikiem wykorzystywania pieśni w języku łacińskim. Wychodził w swych rozważaniach od minionej obecności kultury muzycznej $\mathrm{w}$ gimnazjum, rugowanej stopniowo w kolejnych programach nauczania. Formułował pomysły wykorzystywania pieśni łacińskich, w miarę możliwości na różnych przedmiotach, a więc we współpracy filologów z katechetami i nauczycielami śpiewu. Podkreślał zwłaszcza edukacyjne korzyści ze śpiewania w języku łacińskim na nabożeństwach szkolnych. Proponował rozpoczynanie śpiewem lekcji łaciny, wykonywanie pieśni w języku łacińskim na gimnastyce i na kółkach filologicznych. Zalecał też śpiewanie tekstów poetów antycznych (Owidiusza, Wergiliusza, Katullusa, Horacego) ${ }^{37}$. Sam stworzył zestaw materiałów do realizacji tych zamierzeń, tłumacząc popularne polskie pieśni (patriotyczne, kolędy, utwory ludowe i religijne) i poświęcając na to cały numer swojego pisemka „Palaestra” ${ }^{38}$.

${ }^{34}$ M. Auerbach, Nowy sprzymierzeniec tacińskich zadań szkolnych, PK R. 2, 1936, z. 9-10, s. $689-691$.

35 R. Ganszyniec, Komentarz szkolny do utworów klasycznych [cz. 1-2], PK R. 4, 1938, z. 8-9, s. 512-522; R. 4, 1938, z. 10, s. 620-626.

36 M. Golias, Pracownie filologiczne w szkołach średnich, KK 1931, z. 3, s. 339-342.

37 R. Ganszyniec, Pieśń tacińska w szkole, PK R. 3, 1937, z. 5-7, s. 309-326; idem, Śpiew poezyj horatiańskich w szkole, PK R. 1, 1935, z. 5-6, s. 491-561.

38 Carmina Polona, „Palaestra” 1936, nr 10, s. 1-44. 
Deklarował też zamiar stworzenia specjalnego śpiewnika, zapowiadając jego rychłe wydanie ${ }^{39}$.

W tym miejscu trudno nie podkreślić zasług Ganszyńca jako wydawcy „Palaestry”, a zwłaszcza „Filomaty”, na którego łamach realizował wszechstronną działalność, odgrywając rolę prawdziwego organizatora uczniowskiego ruchu filologicznego, inicjatora tworzenia szkolnych kółek filologicznych, inspirującego młodzież do samodzielnych studiów nad antykiem. Poprzez teksty redakcyjne starał się nawiązywać bezpośredni kontakt z młodym czytelnikiem, oddając mu też do dyspozycji miejsce na łamach periodyku - publikując uczniowskie referaty i przekłady, a nawet wykorzystując projekty graficzne okładek nadesłane w ramach specjalnego konkursu ${ }^{40}$.

Zaangażowanie filologów uniwersyteckich w sprawy edukacji przejawiało się niekiedy nawet krytyką polityki kadrowej władz szkolnych. Franciszek Smolka obliczył w 1928 roku, że w całej Polsce dyrektorzy-filolodzy stanowią od 17 do 39\% w zależności od typu gimnazjum. Ale nawet te $39 \%$ w gimnazjach klasycznych uważał za liczbę zbyt niską i postulował, aby na czele gimnazjum klasycznego stał zawsze filolog klasyczny ${ }^{41}$. Informacje Ganszyńca w nekrologu Matakiewicz o pozamerytorycznych przyczynach jej zwolnienia ze szkoły wywołały z kolei reakcję lwowskiego kuratorium i spór kompetencyjny pomiędzy zarządem głównym PTF a redaktorem „Kwartalnika Klasycznego”. Zarząd PTF bronił decyzji władz kuratoryjnych, Ganszyniec negował zaś prawo towarzystwa do cenzurowania treści czasopisma, podkreślając, że za teksty w nim zamieszczane odpowiada wyłącznie redaktor naczelny ${ }^{42}$. Także kilka lat później wystąpił w „Przeglądzie Klasycznym” w sprawie mianowania Tadeusza Strojnego nowym dyrektorem V Gimnzjum we Lwowie. Urzędnikom kuratorium zarzucał podstępny i nieelegancki sposób zwolnienia poprzedniego kierownika zakładu (filologa klasycznego Jana Schmita) i powołania na jego miejsce matematyka, przeciwnika gimnazjum klasycznego. Publikacja ta sprowokowała kuratorium do wejścia na drogę prawną, co doprowadziło w konsekwencji do decyzji sądowej o konfiskacie części numeru czasopisma ${ }^{43}$.

39 Planowano to na rok 1938, ale zamiar udało się zrealizować dopiero po jego śmierci, gdy śpiewnik ukazał się w ramach wznowionej przez niego w Krakowie „Biblioteczki Filomaty” (R. Gansiniec, Śpiewnik filomatów, Biblioteczka Filomaty nr 40, Kraków 1960).

40 Przykładowo: R. Ganszyniec, Nowy rok szkolny, „Filomata” 1933, nr 52, s. 3-4; 1936, nr 76, s. 195-199; 1938, nr 106, s. 195-196; idem, Ida Filomaci, „Filomata” 1936, nr 82, s. 3-9; idem, Pierwsza lekcja łaciny, „Filomata” 1936, nr 86, s. 195-201; idem, Wynik konkursu ze znajomości kultury starożytnej, „Filomata” 1936, nr 86, s. 226-229.

41 F. Smolka, W sprawie obsadzania stanowisk dyrektorów gimnazjów klasycznych filologami, KK 1928, z. 2, s. 223-224.

42 Sprostowanie [pismo ZG PTF], KK 1932, z. 3, s. 364-365; R. Ganszyniec, Odpowiedź, KK 1932, z. 3, s. 365; Komunikat Wydziału Głównego PTF, KK 1933, z. 1, s. 89-90; R. Ganszyniec, Odpowiedź, KK 1933, z. 1, s. 90-91.

43 R. Ganszyniec, Niesamowitości oświatowe, PK R. 2, 1936, z. 5, s. 385-393; [Wyciąg z protokołu posiedzenia sądu we Lwowie 9 maja 1936 r. oraz Sprostowanie przewodniczącego Sekcji Oddziału Szkoły Średniej Związku Nauczycielstwa Polskiego w Stanisławowie z 28 kwietnia 1936 r.], PK R. 2, 1936, z. 7-8, s. [I-II]. 
We wszystkich analizowanych periodykach pojawiały się oczywiście teksty poruszające szczegółowe problemy z dziejów cywilizacji starożytnych, dostarczające wiedzy historycznej nauczycielom i uczniom. Można zauważyć wyraźną specjalizację, zazwyczaj związaną z profilem zainteresowań badawczych autorów. Szczególnie aktywni na tym polu byli Smolka, Auerbach i Ganszyniec. Ten pierwszy pisał przede wszystkim o różnych aspektach życia w ptolemejskim Egipcie (na podstawie greckich papirusów $)^{44}$. Frapujący dla młodzieży musiał też być cykl, w którym Auerbach prezentował osiągnięcia techniki starożytnych ${ }^{45}$. Ganszyniec natomiast w serii „Żywa starożytność” publikował teksty, których ideą było przerzucanie pomostu pomiędzy antykiem a światem współczesnym ${ }^{46}$ (na przykład w okolicznościowym eseju zamieszczonym w „Filomacie” po śmierci Józefa Piłsudskiego porównywał go do Arystydesa, Cezara i Oktawiana Augusta ${ }^{47}$ ). Podobny cel widoczny jest u Sinki piszącego o antycznym pochodzeniu polskich przysłów ${ }^{48}$ czy o stanie zachowania starożytnego greckiego piśmiennictwa ${ }^{49}$.

Ważną tematyką prezentowaną na łamach czasopism filologicznych były dokonania współczesnej archeologii. Teksty tego typu pisali jednak najczęściej specjaliści (np. w „Kwartalniku Klasycznym” regularnie publikował je archeolog K. Michałowski). Wyjątkowo tylko podobną tematykę podnosili filolodzy - odkrycia w Dura-Europos i prowadzone tam prace archeologiczne relacjonował papirolog Smolka ${ }^{50}$. Popularyzowano również wiedzę o badaniach filologicznych za granicą ${ }^{51}$ i krajowych

44 F. Smolka, Jeden z najstarszych raptularzy, KK 1928, z. 4, s. 389-390; idem, Obrazki rodzajowe na tle protokołów z posiedzeń rad miejskich, KK 1929, z. 2, s. 199-205; idem, Biesiada grecka w Egipcie, „Filomata” 1929, nr 6, s. 35-36; idem, Paradoxa w papirologii, KK 1933, z. 1, s. 35-39; idem, Na marginesie czwartego przykazania, „Filomata” 1933, nr 53, s. 58-60; idem, Prototyp bractwa dobrej śmierci, KK 1934, z. 2, s. 131-136; idem, Jak ma urzędnik spetnić swoje obowiązi?, KK 1934, z. 4, s. 305-308; idem, Gimnazjum w epoce ptolemejskiej, „Filomata” 1935, nr 67, s. 269-272; idem, Z dziedziny charakterystycznych formut, „Eos” R. 37, 1936, z. 2, s. 152-156.

45 M. Auerbach, Z techniki starożytnych Greków, „Filomata” 1930, nr 11, s. 32-35; nr 16, s. 271; nr 19, s. 126; 1931, nr 29, s. 608-609; idem, Platon a matematyka grecka, KK 1932, z. 1, s. 45-56; idem, Automat, „Filomata” 1935, nr 74, s. 138-140; idem, Przyrzady zegarowe u starożytnych Greków i Rzymian, „Eos” R. 25, 1936, nr 1, s. 27-42; idem, Prototyp sikawki pożarnej, „Filomata” 1938, nr 101, s. $519-521$.

46 R. Ganszyniec, Żywa starożytność, „Filomata” 1931, nr 33, s. 790-793; 1931, nr 34, s. 835838; 1931, nr 37, s. 117-120; 1934, nr 57, s. 278-279; 1934, nr 62, s. 29-33; idem, O bogu umierajacym i zmartwychwstajacym, „Filomata” 1934, nr 58, s. 339-346; idem, Rzymianie o wartości sportu, „Filomata” 1934, nr 62, s. 19-20; idem, Stulecie niepodleglości Hellady, „Filomata” 1930, nr 18, s. 64-80; idem, Orszak Dionysosa w Polsce, „Filomata” 1937, nr 90, s. 415-419.

47 Idem, Józef Pitsudski, „Filomata” 1935, nr 71, s. 435-439.

48 T. Sinko, Czy tylko „Polak madry po szkodzie”?, „Filomata” 1938, nr 100, s. 420. Rok później autor opublikował książkę poświęconą temu tematowi (idem, Klasyczne przystowia w polszczyźnie, Lwów 1939).

49 Idem, Ile dziet literatury greckiej zachowało się, a ile przepadto?, „Filomata” 1929, nr 2, s. 51-56.

50 F. Smolka, Jeszcze jedno ognisko kultury hellenistycznej: Dura-Europos, „Eos” R. 37, 1936, z. 4 , s. 513-521.

51 R. Ganszyniec, Filologia klasyczna w Czechostowacji, KK 1928, z. 3, s. 317-329; idem, Studia klasyczne w Bułgarii, KK 1929, z. 3, s. 335-347. 
środowiskach naukowych ${ }^{52}$. Lwowscy i krakowscy profesorowie wspominali też w okolicznościowych tekstach sylwetki wybitnych filologów, między innymi Franciszka Terlikowskiego $0^{53}$, Aleksandra Radeckiego ${ }^{54}$, Ludwika Ćwiklińskiego ${ }^{55}$, Kazimierza Morawskiego ${ }^{56}$, Piotra Bieńkowskiego ${ }^{57}$, Konstantego Chylińskiego ${ }^{58}$ i Zygmunta Węclewskiego ${ }^{59}$. Publikowali także liczne recenzje i omówienia prac naukowych nie tylko z dziedziny filologii, ale także historii starożytnej, patrystyki, archeologii i językoznawstwa. Niektóre z recenzowanych dzieł służyły do snucia bardziej ogólnych refleksji. Przykładowo Sinko omówił książkę Przychockiego Kultura klasyczna w kulturze wspótczesnej, stanowiącą zapis sześciu wykładów radiowych poświęconych motywom antycznym w pedagogice, historiografii, prawie, języku, literaturze. Zwrócił uwagę, że praca ta wpisuje się w nurt aktualizacji wiedzy antycznej, stwierdzając: „powojenna fala antyhumanistyczna pobudziła filologów do postawienia przed oczyma współczesnych zwierciadła, w którym by się mogli przypatrzeć antycznej spuściźnie w dorobku cywilizacyjnym Europy" ${ }^{60}$. W ocenie Sinki autor osiągnął propagandowy efekt upowszechnienia wiedzy filologicznej, wpływając na ożywienie środowiska: „Filologowie starszej daty, którzy wskutek tyloletnich ataków na ich przedmiot utracili może wiarę w żywotność antyku, odzyskają ją, a młodsi nabiorą otuchy i dumy, że przecież to rzecz wspaniała być filologiem i wiedzieć, dlaczego to dziś owoce kultury europejskiej mają jeszcze zapach i smak antyczny" ${ }^{\prime 1}$. Autorem wielu recenzji był Adolf Bednarowski, lektor filologii klasycznej na UJK zajmujący się dydaktyką łaciny i greki. Publikował regularnie omówienia wydawnictw poświęconych nauczaniu szkolnemu ${ }^{62}$. W „Kwartalniku Klasycznym” zamieszczał także notki krytyczne o tekstach z rocznych „Sprawozdań” dyrekcji gimnazjów ${ }^{63}$.

52 J. Smereka, Filologia klasyczna w Uniwersytecie Lwowskim do czasów Zygmunta Węclewskiego i Ludwika Ćwiklińskiego, „Eos” R. 38, 1937, z. 1, s. 61-75.

53 F. Smolka, Franciszek Terlikowski [1851-?], KK 1928, z. 3, s. 336-337.

54 W. Chodaczek, Aleksander Radecki [1849-1928], KK 1929, z. 1, s. 101-103.

55 S. Witkowski, Z działalności naukowej Ludwika Ćwiklińskiego, KK 1934, z. 2, s. XX-XXIII.

56 S. Hammer, Kazimierz Morawski jako filolog i humanista, „Eos” R. 28, 1925, s. 229-244.

57 E. Bulanda, Piotr Bieńkowski [1865-1925], „Eos” R. 28, 1925, s. 245-254.

58 J. Smereka, Śp. profesor Konstanty Chyliński [1881-1939], „Eos” R. 40, 1939, z. 2, s. 1-12.

59 Idem, Pierwszy filolog-Polak na Uniwersytecie Jana Kazimierza Zygmunt Węclewski [18241887]. W 50-ta rocznicę śmierci, „Eos” R. 39, 1938, z. 2, s. 217-238.

${ }_{60}$ T. Sinko (rec.), G. Przychocki, Kultura klasyczna w kulturze wspótczesnej, Kraków-Warszawa 1929, KK 1930, z. 1, s. 223.

61 Ibidem, s. 224.

62 A. Bednarowski (rec.), J. Pawlikowski, Jak uczyć języka języka łacińskiego w gimnazjum?, Kraków 1930, KK 1931, z. 2 s. 272-273; idem (rec.), Słownik języka tacińskiego, oprac. W. Wróblewski, Warszawa 1931, KK 1931, z. 3, s. 449-450.

63 A. Bednarowski (rec.), R. Niemiec, Nauczanie początków języka łacińskiego w typie humanistycznym [cz. I] [w:] Sprawozdanie XII. dyrekcji państwowego gimnazjum IV. im. H. Sienkiewicza w Krakowie za rok szkolny 1929/1930, Kraków 1930, s. 5-21; R. Niemiec, Nauczanie początków języka tacińskiego w typie humanistycznym [cz. II] [w:] Sprawozdanie XIII. dyrekcji państwowego gimnazjum IV. w Krakowie za rok szkolny 1930/1931, Kraków 1931, s. 5-10, KK 1931, z. 2, s. 272 [dot. cz. I]; 1932, z. 1, s. 101 [dot. cz. II]; idem (rec.), A. Wiśniewski, Próba spolszczenia homerowych wyrazów okrętowych 
Funkcje pełnione w Polskim Towarzystwie Filologicznym przez naukowców $\mathrm{z}$ uniwersytetów krakowskiego i lwowskiego obligowały ich do referowania działalności organizacyjnej. W firmowanych przez PTF czasopismach zamieszczano więc protokoły zebrań, raporty finansowe, okresowe sprawozdania oraz teksty okolicznościowe $^{64}$. Publikacje te miały służyć nie tylko dokumentowaniu, ale też popularyzowaniu celów Towarzystwa i przyciągnięciu nowych członków, wśród których liczną grupę stanowili nauczyciele gimnazjalni. Ci ostatni mieli też własne specjalistyczne gremia - ogniska metodyczne ${ }^{65}$. Organizowali również regularne konferencje. I tak w 1933 roku odbyło się spotkanie nauczycieli filologii klasycznej lwowskich gimnazjów, którego przebieg szczegółowo zrelacjonował w „Kwartalniku Klasycznym” Mikołaj Szczerbański, sekretarz PTF, a jednocześnie lektor języka łacińskiego na UJK. W trakcie sympozjum wygłaszali referaty i zabierali głos w dyskusji pracownicy katedr filologicznych uniwersytetu we Lwowie: Marian Golias, Emil Urich, Marian Auerbach, Adolf Bednarowski, Franciszek Smolka, Jan Smereka i Władysław Chodaczek ${ }^{66}$.

Specyficzną formą pisarstwa czasopiśmiennego były opisy podróży. Wśród nich znalazły się zamieszczone w „Kwartalniku Klasycznym” tekst Sinki U stóp Heliko$n u^{67}$ oraz recenzja książki tegoż Od Olimpu do Olimpii. Przedstawiono w niej przebieg wyprawy, podczas której Sinko „wspólnie z M. Rozmarynowiczem i T. Skiminą zwiedził cały kraj, koleją, od Saloniki przez Larissę, Teby, Delfy, Ateny, Pireus, Eleusis, aż do Nauplii, Megary, Koryntu, Argos, Myken, Tirynsu i Olimpii, by z Patras wrócić drogą na Brindisi” ${ }^{68}$. Na podstawie własnych doświadczeń z peregrynacji po strefie śródziemnomorskiej Jerzy Kowalski pisał o potrzebie konfrontacji treści antycznych dzieł literackich z materialnymi reliktami przeszłości. Uważał, że filolog powinien znać zabytki archeologiczne, gdyż pomogą mu lepiej zrozumieć przeszłośćc ${ }^{69}$. Podobny wniosek w odniesieniu do nauczycieli-filologów sformułował Golias, który uważał, że obok teoretycznej znajomości języków klasycznych i kultury antycznej potrzebna jest także wiedza oparta „na autopsji i przeżyciu”. Refleksja ta towarzyszyła jego relacji z wycieczki do Grecji zorganizowanej dla nauczycieli przez MWRiOP w 1931 roku. Zgłosiło się na nią 20 filologów - w tym 6 z obszaru kuratorium lwow-

i morskich [w:] Sprawozdanie Państwowego Gimnazjum w Kęnie za rok szkolny 1930/1931, Kęno 1931, s. 3-16, KK 1932, nr 1, s. 100-101; idem (rec.), J. Fränkel, M. Glińska-Rawska, Z. Mirtyński, Przyczynki i materiaty do metodyki ćwiczeń redakcyjnych [w:] Sprawozdanie Dyrekcji Państwowego Gimnazjum w Trembowli za rok szkolny 1933/1934, Trembowla 1934, s. 3-44, KK 1934, z. 1, s. 343-344.

64 R. Ganszyniec, Rok filologiczny w Polsce, KK 1928, z. 2, s. 209-217; idem, Rok filologiczny $w$ Polsce [cz. 1-2], KK 1929, z. 2, s. 239-244; 1929, z. 4, s. 537-554. W 1934 r. M. Auerbach dokonat podsumowania czterdziestoletniego dorobku naukowego PTF (M. Auerbach, Rzut oka na ruch naukowy Polskiego Towarzystwa Filologicznego, KK 1934, z. 2, s. IX-XIX).

${ }_{65}$ R. Ganszyniec, Ogniska metodyczne dla filologii klasycznej, PK R. 1, 1935, z. 1, s. 7-12; R. 1, 1935 , z. 2, s. $65-83$.

${ }_{66}$ M. Szczerbański, Konferencja nauczycieli filologii klasycznej gimnazjów lwowskich [cz. 1-2], KK 1933, z. 2, s. 184-188; 1933, z. 3, s. 249-260.

67 T. Sinko, Ustóp Helikonu, KK 1927, z. 1, s. 37-54.

68 G. Przychocki (rec.), T. Sinko, Od Olimpu do Olimpii, Warszawa 1928, KK 1929, z. 4, s. 525.

69 J. Kowalski, Wymowa ruin, KK 1928, z. 1, s. 58-92. 
skiego i 3 z Krakowa. Kierownictwo naukowe sprawował Kazimierz Michałowski ${ }^{70}$. Kilka lat później przebieg podobnej wycieczki - tym razem do Italii i na Sycylię zrelacjonował Władysław Chodaczek ${ }^{71}$.

Zarówno te wspólne wyprawy nauczycieli i naukowców, jak i tematyka czasopism redagowanych przez uniwersyteckich filologów pokazują, jak ścisłe były w tamtym okresie związki uniwersytetu ze szkołą i jak wielkie zaangażowanie uczelni i jej pracowników w życie szkolne. Wynikało to z różnych względów. Jednym z ważniejszych wydaje się okoliczność, że wielu spośród zatrudnionych na uniwersytetach badaczy wywodziło się z grona nauczycieli gimnazjalnych lub łączyło działalność naukową z pracą w szkole. Pozwalało im to lepiej rozumieć potrzebę popularyzacji, w publikacjach popularnonaukowych potrafili zaś dostosować język do percepcji przeciętnego odbiorcy (szczególnie ważne było to na łamach „Filomaty” adresowanego przede wszystkim do młodzieży szkolnej). Mieli też świadomość, iż propagując swoją dziedzinę wiedzy, bronili jednocześnie ideałów humanistycznych, przekazywanych dzięki wykształceniu klasycznemu.

\section{BIBLIOGRAFIA}

Prasa

„Eos” (1918-1939)

„Filomata” (1929-1939)

„Gazeta Lwowska”, 29 X 1930 r.

„Kwartalnik Klasyczny” (1927-1934)

„Palaestra” (1930-1936)

„Przegląd Klasyczny” (1935-1939)

\section{Literatura przedmiotu}

Auerbach M., Gramatyka łacińska, Lwów 1929.

Bieżuńska-Małowist I., Ryszard Gansiniec (1888-1958), „Meander” R. 13, 1958, s. 301306.

Draus J., Uniwersytet Jana Kazimierza we Lwowie 1918-1946, Kraków 2007.

Dybiec J., Uniwersytet Jagielloński 1918-1939, Kraków 2000.

70 M. Golias, Ostatnia wycieczka do Grecji: jej organizacja, cel i wyniki, KK 1932, z. 1, s. 57-65.

${ }^{71}$ W. Chodaczek, Sprawozdanie z wycieczki nauczycieli-filologów do Italii i na Sycylię, która odbyta się w dniach od 20 marca do 19 kwietnia 1937 r., „Eos” R. 38, 1937, z. 3, s. 396-413. 
Dybiec J., Uniwersytet Jagielloński a szkolnictwo średnie (1918-1939) [w:] Ojczyzna blizsza i dalsza. Studia historyczne ofiarowane Feliksowi Kirykowi w sześćdziesiąta rocznice urodzin, red. J. Chrobaczyński, A. Jureczko, M. Śliwa, Kraków 1993, s. 560-569.

Historia filologii klasycznej na Uniwersytecie Jagiellońskim, http://www.ifk.filg.uj.edu.pl/ historia [dostęp: 15.09.2017].

Kaczor I., Znaczące postacie łódzkiej filologii klasycznej: Jan Oko, Jerzy Schnayder, Marian Golias, Stefan Oświecimski, „Collectanea Philologica” 2003, vol. 7, s. 97-101.

Królczyk K., Polscy badacze starożytności na Uniwersytecie Lwowskim (1873-1939) szkic do portretu [w:] „,Haec mihi in animis vestris templa”. Studia classica in Memory of Professor Lesław Morawiecki, oprac. P. Berdowski, B. Blahaczek, Rzeszów 2007, s. $23-46$.

Lewartowicz A., ,Przegląd Klasyczny”, „Meander” R. 69, 2014, s. 141-161.

Madyda W., Z dziejów filologii klasycznej w Uniwersytecie Jagiellońskim [w:] Wydziat Filologiczny Uniwersytetu Jagiellońskiego. Historia katedr, red. W. Taszycki, A. Zaręba, Kraków 1964, s. 1-94.

Plezia M., Gustaw Przychocki, „Meander” R. 39, 1984, s. 57-78.

Plezia M., Kazimierz Morawski, „Rocznik Biblioteki PAN w Krakowie” R. 31, 1986, s. 7997.

Popiak W., Łacina i greka w polskiej szkole w latach 1919-1939. Programy, metody, podręczniki, Warszawa 2005.

Sinko T., Gramatyka łacińska, Warszawa-Poznań 1924 (wyd. 2, 1925, wyd. 3, 1930).

Turasiewicz R., Ryszard Ganszyniec jako historyk greckiej literatury, „Meander” R. 44, 1989, s. 369-382.

Uniwersytet Jana Kazimierza we Lwowie. Academia militans, red. A. Redzik, Kraków 2015.

Złota Księga Wydziału Filologicznego, red. J. Michalik, W. Walecki, Kraków 2000. 